\title{
Article \\ A Concise Total Synthesis of the Fungal Isoquinoline Alkaloid TMC-120B
}

\author{
Ahmad K. Haidar ${ }^{1}$, Niels D. Kjeldsen ${ }^{2}$, Nikolaj S. Troelsen $\left.{ }^{1}{ }^{(}\right)$, Viola Previtali ${ }^{1}{ }^{(\mathbb{C}}$, Kasper P. Lundquist ${ }^{1}{ }^{(\mathbb{D}}$, \\ Thomas O. Larsen ${ }^{3}$ and Mads H. Clausen ${ }^{1, *(D)}$ \\ 1 Center for Nanomedicine and Theranostics, Department of Chemistry, Technical University of Denmark, \\ Kemitorvet 207, 2800 Kongens Lyngby, Denmark; ahmhai@biosustain.dtu.dk (A.K.H.); \\ nikolaj.s.troelsen@outlook.com (N.S.T.); Viola.Previtali@iit.it (V.P.); kaslun@kemi.dtu.dk (K.P.L.) \\ 2 NCK A/S, Rugmarken 28, 3520 Farum, Denmark; ndk@nck.dk \\ 3 Department of Biotechnology and Biomedicine, Technical University of Denmark, Søltofts Plads, Building 221, \\ 2800 Kongens Lyngby, Denmark; tol@bio.dtu.dk \\ * Correspondence: mhc@kemi.dtu.dk
}

check for

updates

Citation: Haidar, A.K.; Kjeldsen, N.D.; Troelsen, N.S.; Previtali, V.; Lundquist, K.P.; Larsen, T.O.; Clausen, M.H. A Concise Total Synthesis of the Fungal Isoquinoline Alkaloid TMC-120B. Molecules 2022, 27, 521. https://doi.org/10.3390/ molecules 27020521

Academic Editor: Antonio Massa

Received: 2 December 2021

Accepted: 28 December 2021

Published: 14 January 2022

Publisher's Note: MDPI stays neutral with regard to jurisdictional claims in published maps and institutional affiliations.

Copyright: (C) 2022 by the authors. Licensee MDPI, Basel, Switzerland. This article is an open access article distributed under the terms and conditions of the Creative Commons Attribution (CC BY) license (https:// creativecommons.org/licenses/by/ $4.0 /)$.

\begin{abstract}
Recent reports of antiepileptic activity of the fungal alkaloid TMC-120B have renewed the interest in this natural product. Previous total syntheses of TMC-120B comprise many steps and have low overall yields (11-17 steps, 1.5-2.9\% yield). Thus, to access this compound more efficiently, we herein present a concise and significantly improved total synthesis of the natural product. Our short synthesis relies on two key cyclization steps to assemble the central scaffold: isoquinoline formation via an ethynyl-imino cyclization and an intramolecular Friedel-Crafts reaction to form the furanone.
\end{abstract}

Keywords: isoquinolines; alkaloids; epilepsy

\section{Introduction}

The fuoroisoquinoline alkaloid TMC-120B (1) was first isolated from the fungus Aspergillus ustus by Kamutsubara et al. in 1999 (Figure 1) [1]. TMC-120B was initially discovered as a modulator of interleukin-5 mediated eosinophil viability [2], but has recently been reported to also exhibit antiepileptic activity in a Zebrafish model [3]. Epilepsy describes a group of serious neurological disorders that are characterized by recurrent epileptic seizures $[4,5]$ and has been estimated to affect as many as 50 million people worldwide in 2016 [6]. While many patients experience lasting seizure remissions with present antiepileptic drugs (e.g. sodium valproate, lamotrigine, topiramate, and carbamazepine), [5,7] about one in three patients remain insensitive to current treatment options (drug-resistant epilepsy) [7,8]. Furthermore, TMC-120B is non-cytotoxic in human cancer cell lines [9] and has shown activity in the $6 \mathrm{~Hz}$ psychomotor mouse model for epilepsy, [10] suggesting that further biological investigations are warranted [11].

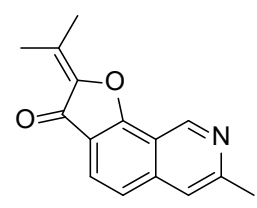

1

Figure 1. The fungal natural product TMC-120B (1).

With renewed interest in the biological properties of $\mathbf{1}$, a need for convenient access to this natural product has emerged [3]. The first total synthesis of $\mathbf{1}$ was reported by Hibino et al. in 2003 and consisted of 17 steps from 2,4-dihydroxybenzaldehyde (3) with an overall yield of $1.5 \%[12,13]$. In 2012, the same group reported an improved total synthesis of $\mathbf{1}$ in 
11 steps starting from methyl $\beta$-resorcylate (5) with an overall yield of 2.9\% (Scheme 1) [14]. However, in order to access larger quantities of this natural product more efficiently, and potentially analogues thereof, a shorter and more efficient route is required. Thus, we herein present a concise and significantly improved total synthesis of $\mathbf{1}$ (Scheme 1). Moreover, in the first total synthesis, the isoquinoline framework 2 was constructed from $\mathbf{3}$ in 11 steps (7\% overall yield), improved by the same group by constructing 4 from 5 in seven steps (16\% overall yield); in our work, we simplified the synthesis of isoquinoline framework 6 into three steps (52\% overall yield).

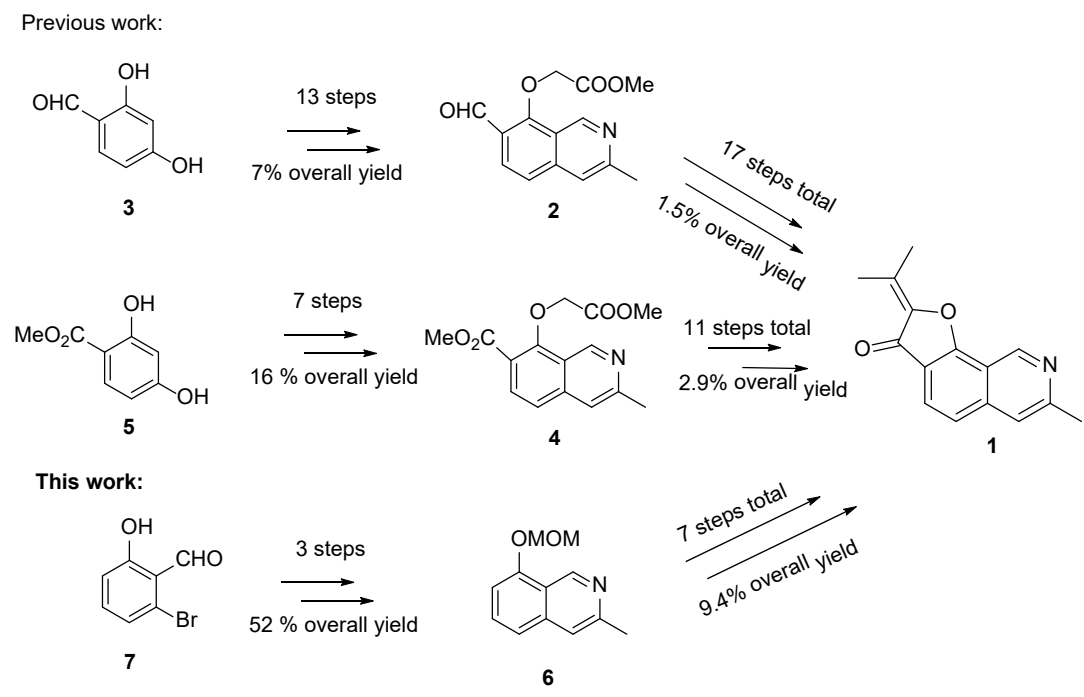

Scheme 1. Two previously reported total syntheses of TMC-120B (1) $[12,14]$ and this work.

\section{Results and Discussion}

Total synthesis of $\mathbf{1}$ was envisioned using two key cyclization steps for assembly of the central scaffold. An intramolecular Friedel-Crafts reaction was planned to form the final furanone ring while an ethynyl-imine cyclization was selected to form the isoquinoline scaffold (Scheme 2).
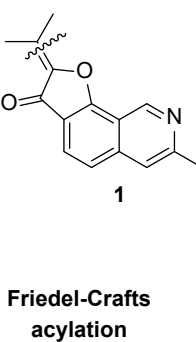

acylation

EtOOC - s. $^{s^{5}}-\frac{1}{2}$
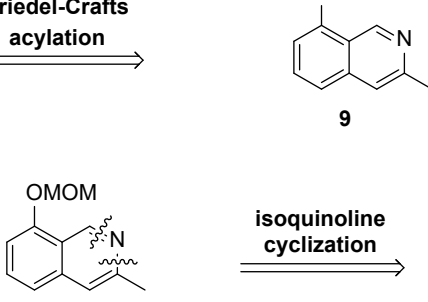

6

$$
\begin{gathered}
\text { isoquinoline } \\
\text { cyclization }
\end{gathered}
$$

Sonogashira

\& protection

$\stackrel{\text { \& protection }}{\longrightarrow}$

$\mathrm{OH}$
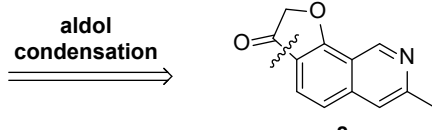

8

deprotection \& alkylation<smiles>CC#C[Te](=O)(O)c1cccc(OC)c1C=O</smiles><smiles>Cc1cccc(Br)c1C=O</smiles>

7

Scheme 2. Retrosynthetic analysis of $\mathbf{1}$ showing two key cyclization steps-intramolecular FriedelCrafts acylation and isoquinoline formation. 
The synthetic route to access $\mathbf{1}$ is shown in Scheme 3. From readily available 2bromo-6-hydroxybenzaldehyde (7), an initial Sonogashira coupling $[15,16]$ with propyne was accomplished to afford $\mathbf{1 1}$ at a $69 \%$ yield. Initial attempts to form the isoquinoline scaffold from $\mathbf{1 0}$ were unsuccessful both via conversion of $\mathbf{1 0}$ into the corresponding tertbutylimine followed by a copper-catalyzed imino-annulation [17] or attempting a tandem imine formation and subsequent ethynyl-imino cyclization reaction with ammonia [18]. Methoxymethyl acetal (MOM) protection of the phenol was then performed to generate intermediate 8 in $84 \%$ yield [19]. While imino-annulation via the tert-butylimine still did not occur, formation of the isoquinoline scaffold was accomplished using the tandem imine and ethynyl-imino cyclization sequence to afford 6 at an $89 \%$ yield. This presents a significant improvement over previous efforts to synthesize the core isoquinoline scaffold of $\mathbf{1}$ via thermal aza-electrocyclic reactions (46\% yield) [14]. The isoquinoline cyclization was also carried out by formation of the corresponding $O$-allyl oxime of $\mathbf{1 0}$ and a subsequent silver trifluoro-methane-sulfonate/triflic acid (AgOTf/TFOH) co-catalyzed redox reaction, but only provided 6 at a $48 \%$ yield over two steps [20].<smiles>CC#Cc1cccc(O)c1C=O</smiles><smiles>CC#Cc1cccc(OC)c1C=O</smiles><smiles>CCOC(=O)COc1cccc2cc(C)ncc12</smiles><smiles>Cc1cc2ccc3c(c2cn1)OCC3=O</smiles><smiles>[TeH]</smiles><smiles>CC(C)=C1Oc2c(ccc3cc(C)ncc23)C1=O</smiles>
1

Scheme 3. Total synthesis of TMC-120B (1). Reagents and conditions: (a) propyne, $\mathrm{PdCl}_{2}\left(\mathrm{PPh}_{3}\right)_{2}$, $\mathrm{CuI}, \mathrm{Et}_{3} \mathrm{~N}, 55{ }^{\circ} \mathrm{C}, 24 \mathrm{~h}, 69 \%$; (b) MOMCl, DIPEA, $\mathrm{CH}_{2} \mathrm{Cl}_{2}, 40{ }^{\circ} \mathrm{C}, 16 \mathrm{~h}, 84 \%$; (c) $\mathrm{NH}_{3}, 80^{\circ} \mathrm{C}, 7 \mathrm{~h}, 89 \%$; (d) $\mathrm{HCl}, \mathrm{MeOH}$, reflux, $3 \mathrm{~h}, 90 \%$; (e) ethyl bromoacetate, $\mathrm{NaOEt}, \mathrm{DMF}, 12 \mathrm{~h}, 73 \%$; (f) $i . \mathrm{NaOH}, \mathrm{EtOH}$, $1 \mathrm{~h}$, ii. $\mathrm{SOCl}_{2}$, reflux, $1 \mathrm{~h}$, iii. $\mathrm{AlCl}_{3}, 1 \mathrm{~h}, 79 \%$; (g) $p$ - $\mathrm{TsOH} \cdot \mathrm{H}_{2} \mathrm{O}$, acetone, DCE, reflux, $5 \mathrm{~h}, 35 \%$.

MOM deprotection under acidic conditions proceeded at a $90 \%$ yield to afford isoquinolinol 12. This enabled alkylation of the phenol with ethyl bromoacetate to give the second key intermediate 9 in 73\% yield. Instead of a Dieckmann condensation [21] and decarboxylation sequence to form the final furanone ring as previously reported, [12-14] cyclization was realized using an intramolecular Friedel-Crafts acylation [22]. Hydrolysis to the carboxylic acid and subsequent conversion to the corresponding acid chloride was achieved with sodium hydroxide $(\mathrm{NaOH})$ and thionyl chloride $\left(\mathrm{SOCl}_{2}\right)$, followed by the addition of aluminum trichloride to assemble the complete scaffold of TMC-120B (1) in $79 \%$ yield over two steps. The total synthesis of $\mathbf{1}$ was then finalized using an aldol con- 
densation between 8 and acetone under acidic conditions at a 35\% yield. Comparison of NMR spectroscopic data with that of previous reports and isolation from natural extracts confirmed the identity of $\mathbf{1}[1,13]$.

\section{Experimental}

\subsection{General Methods}

Commercially available reagents were used without further purification and all solvents were of HPLC quality. Unless otherwise stated, reactions were carried out under an atmosphere of nitrogen and heating was performed in an oil bath. Reactions were monitored by thin layer chromatography (TLC) and/or reversed-phase ultra-performance liquid chromatography mass spectrometry (RP-UPLC-MS). Analytical TLC was conducted on Merck aluminum sheets covered with silica (C60). The plates were either visualized under UV-light or stained by dipping in a developing agent followed by heating. Potassium permanganate $\mathrm{KMnO}_{4}\left(3 \mathrm{~g}\right.$ in water $(300 \mathrm{~mL})$ along with potassium carbonate $\mathrm{K}_{2} \mathrm{CO}_{3}$ $(20 \mathrm{~g}))$ was used as developing agent. Flash column chromatography was performed using Merck Geduran ${ }^{\circledR}$ Si $60(40-63 \mu \mathrm{m})$ silica gel. Analytical RP-UPLC-MS (ESI) analysis was performed on a S2 Waters AQUITY RP-UPLC system equipped with a diode array detector using an Thermo Accucore C18 column $\left(\mathrm{d} 2.6 \mu \mathrm{m}, 2.1 \times 50 \mathrm{~mm}\right.$; column temp: $50{ }^{\circ} \mathrm{C}$; flow: $1.0 \mathrm{~mL} / \mathrm{min})$. Eluents $\mathrm{A}\left(10 \mathrm{mM} \mathrm{NH}_{4} \mathrm{OAc}\right.$ in $\left.\mathrm{H}_{2} \mathrm{O}\right)$ and $\mathrm{B}(10 \mathrm{mM}$ ammonium acetate $\mathrm{NH}_{4} \mathrm{OAc}$ in acetonitrile $\mathrm{MeCN}$ ) were used in a linear gradient (5\% B to $100 \% \mathrm{~B}$ ) for $2.4 \mathrm{~min}$ and then held for $0.1 \mathrm{~min}$ at $100 \% \mathrm{~B}$ (total run time: $2.6 \mathrm{~min}$ ). The LC system was coupled to a SQD mass spectrometer. All new compounds were characterized by ${ }^{1} \mathrm{H} \mathrm{NMR},{ }^{13} \mathrm{C}$ NMR, IR, HRMS (ESI), and melting point.

NMR data were acquired at $298 \mathrm{~K}$ using a $400 \mathrm{MHz}$ Bruker AVANCE III HD spectrometer equipped with a Prodigy CryoProbe. The chemical shifts $(\delta)$ are reported in parts per million (ppm) and the coupling constants $(J)$ in Hz. For spectra recorded in dimethyl sulfoxide DMSO- $d_{6}$, chemical shifts are reported relative to the signal for DMSO- $d_{5}(\delta 2.50$ ppm for ${ }^{1} \mathrm{H}$ NMR and $\delta 39.52 \mathrm{ppm}$ for $\left.{ }^{13} \mathrm{C} \mathrm{NMR}\right)$. For spectra recorded in $\mathrm{CDCl}_{3}$, chemical shifts are reported relative to the signal for $\mathrm{CHCl}_{3}\left(\delta 7.26 \mathrm{ppm}\right.$ for ${ }^{1} \mathrm{H} \mathrm{NMR}$ and $\delta 77.16 \mathrm{ppm}$ for ${ }^{13} \mathrm{C}$ NMR). For spectra recorded in $\mathrm{D}_{2} \mathrm{O},{ }^{1} \mathrm{H}$ chemical shifts are reported relative to the signal for HDO ( $\delta 4.79$ ppm for ${ }^{1} \mathrm{H}$ NMR) and ${ }^{13} \mathrm{C}$ chemical shifts are reported relative to the signal for DMSO- $d_{6}$ (added as an internal standard). NMR data was analyzed using MestReNova (v11.0.0-17609) by Mestrelab Research S.L. All NMR Spectra for compounds 1, 5, 6 hydrolyzed, 7, 8, 9 and 10 can be found in Supplementary Materials.

IR analysis was performed on a Bruker Alpha FT-IR spectrometer. Melting points were obtained using a Stuart SMP30 melting point apparatus and are uncorrected. Analytical LCHRMS (ESI) analysis was performed on an Agilent 1100 RP-LC system or a Waters Alliance 2695. The Agilent 1100 was equipped with a diode array detector using a Phenomenex Luna C18 column $\left(\mathrm{d} 3 \mu \mathrm{m}, 2.1 \times 50 \mathrm{~mm}\right.$; column temp: $40{ }^{\circ} \mathrm{C}$; flow: $\left.0.4 \mathrm{~mL} / \mathrm{min}\right)$. Eluents A $\left(0.1 \% \mathrm{HCO}_{2} \mathrm{H}\right.$ in $\left.\mathrm{H}_{2} \mathrm{O}\right)$ and $\mathrm{B}\left(0.1 \%\right.$ formic acid $\mathrm{HCO}_{2} \mathrm{H}$ in $\left.\mathrm{MeCN}\right)$ were used in a linear gradient ( $20 \%$ B to $100 \% \mathrm{~B}$ ) in a total run time of $15 \mathrm{~min}$. The LC system was coupled to a Micromass LCT orthogonal time-of-flight mass spectrometer equipped with a Lock Mass probe operating in positive electrospray mode. The Waters Alliance 2695 was equipped with a diode array detector without a column. Eluents $\mathrm{A}\left(0.1 \% \mathrm{HCO}_{2} \mathrm{H}\right.$ in $\left.\mathrm{H}_{2} \mathrm{O}\right)$ and $\mathrm{B}$ $\left(0.1 \% \mathrm{HCO}_{2} \mathrm{H}\right.$ in $\left.\mathrm{MeCN}\right)$ were used as a 1:1 mixture in a linear gradient with a total run time of $3 \mathrm{~min}$. The LC system was coupled to a Micromass LCT Premier XE operating in positive electrospray mode. All IR spectra for compounds 1, 5, 6 hydrolyzed, 7, 8, 9 and 10 can be found in Supplementary Materials.

\subsection{2-Hydroxy-6-(prop-1-yn-1-yl)benzaldehyde (11)}

In a 3-necked, $\mathrm{N}_{2}$-flushed, $6 \mathrm{~L}$ reactor equipped with mechanical stirrer, condenser and heating mantle was mixed triethylamine $\left(\mathrm{NEt}_{3}\right)\left(320 \mathrm{~mL}\right.$, degassed with $\left.\mathrm{N}_{2}\right)$ and 2-bromo-6-hydroxybenzaldehyde (20.5 g, $102 \mathrm{mmol})$. The mixture was heated to $41{ }^{\circ} \mathrm{C}$ and Bis(triphenylphosphine)palladium chloride $\left(\mathrm{Pd}\left(\mathrm{PPh}_{3}\right)_{2} \mathrm{Cl}_{2}\right)(3.72 \mathrm{~g}, 5.3 \mathrm{mmol})$ was added 
followed by copper iodide (CuI) $(1.82 \mathrm{~g}, 9.6 \mathrm{mmol})$. The mixture was heated to $54{ }^{\circ} \mathrm{C}$ during $9 \mathrm{~min}$. To the mixture was added propyne $(5 \mathrm{wt} \%$ in THF, $2110 \mathrm{~mL}, 2.337 \mathrm{~mol}$ ) during $19 \mathrm{~min}$. This was followed by significant gas evolution. The mixture was stirred at $54-58^{\circ} \mathrm{C}$ for $17 \mathrm{~h}$. At this point HPLC indicated $98.9 \%$ conversion of starting material to product. To the mixture was added propyne ( $5 \mathrm{wt} \%$ in THF, $100 \mathrm{~mL}$ ) and the mixture was stirred for 1 $\mathrm{h}$ at $54-56{ }^{\circ} \mathrm{C}$. This resulted in no further conversion of starting material to product. To this mixture, ammonium chloride was added $\left(\mathrm{NH}_{4} \mathrm{Cl}\right)(25 \mathrm{wt} \%$ in water, $1200 \mathrm{~mL})$. The mixture was transferred to a separatory funnel and the phases separated. The aqueous layer was extracted with $3 \times 800 \mathrm{~mL}$ ethyl acetate (EtOAc). The pooled organic layers were dried over anhydrous sodium sulfate $\left(\mathrm{Na}_{2} \mathrm{SO}_{4}\right)(242 \mathrm{~g})$ and concentrated on a rotary evaporator (T,bath $=50^{\circ} \mathrm{C}$ ). The crude product was purified by flash column chromatography on silica (433 g). Eluent: heptanes/EtOAc 93:7 v/v). This gave compound $11(11.21 \mathrm{~g}, 70 \mathrm{mmol}, 69 \%$ yield, HPLC purity: $91.8 \%$ ) as a red oil, which slowly crystallized.

$R_{\mathrm{f}}=0.57$ (EtOAc/heptane 2:8); m.p.: $36-38{ }^{\circ} \mathrm{C} ;{ }^{1} \mathrm{H}$ NMR $\left(400 \mathrm{MHz}, \mathrm{CDCl}_{3}\right) \delta 11.66$ $(\mathrm{s}, 1 \mathrm{H}), 10.43(\mathrm{~s}, 1 \mathrm{H}), 7.40(\mathrm{t}, J=7.5 \mathrm{~Hz}, 1 \mathrm{H}), 7.00(\mathrm{~d}, J=7.5 \mathrm{~Hz}, 1 \mathrm{H}), 6.89(\mathrm{~d}, J=7.5 \mathrm{~Hz}$, $1 \mathrm{H}), 2.12(\mathrm{~s}, 3 \mathrm{H}) ;{ }^{13} \mathrm{C}\left\{{ }^{1} \mathrm{H}\right\}$ NMR $\left(101 \mathrm{MHz}, \mathrm{CDCl}_{3}\right) \delta 197.4,162.4,136.7,128.6,124.5,112.0$, 117.6, 93.9, 75.3, 4.7; IR (neat) $\mathrm{cm}^{-1}$ : 3130 (br., O-H), 2877 (m, C(O)-H), 2757 (m, C(O)-H) $2229(\mathrm{~m}, \mathrm{C} \equiv \mathrm{C}) .1651(\mathrm{~s}, \mathrm{C}=\mathrm{C})$; HRMS (ESI) $\mathrm{m} / z[\mathrm{M}+\mathrm{H}]^{+}$calcd for $\mathrm{C}_{10} \mathrm{H}_{9} \mathrm{O}_{2}: 161.0603$, found: 161.0606 .

\subsection{2-(Methoxymethoxy)-6-(prop-1-yn-1-yl)benzaldehyde (10)}

In a $250 \mathrm{~mL} \mathrm{~N}_{2}$-flushed reactor equipped with mechanical stirrer, compound 11 (10.99 $\mathrm{g}, 68.6 \mathrm{mmol}$ ) was dissolved in dichloromethane (DCM) (water content: 50 ppm, $200 \mathrm{~mL}$ ). To the mixture was added diisopropylethylamine (DIPEA) (water content: $720 \mathrm{ppm}, 50 \mathrm{~mL}$ ). The mixture was cooled to $3{ }^{\circ} \mathrm{C}$. To the mixture was added MOM-Cl $(11.0 \mathrm{~mL}, 143 \mathrm{mmol})$ for $3 \mathrm{~min}$ at a temperature of $3-5{ }^{\circ} \mathrm{C}$. The mixture was heated to $41^{\circ} \mathrm{C}$ and stirred at $40-41{ }^{\circ} \mathrm{C}$ for $3 \mathrm{~h}$. At this point HPLC indicated $99.4 \%$ conversion of the starting material to product. The mixture was cooled to $-3{ }^{\circ} \mathrm{C}$ and $1 \mathrm{M}$ hydrochloric acid $(50 \mathrm{~mL})$ was added for $3 \mathrm{~min}$. This caused the temperature to increase to $4{ }^{\circ} \mathrm{C}$. The mixture was extracted with $3 \times 300 \mathrm{~mL}$ EtOAc. The combined organic layers were washed with sodium hydrogen carbonate $\left(\mathrm{NaHCO}_{3}\right)(6 \mathrm{wt} \%$ in water, $550 \mathrm{~mL})$ and then sodium chloride $(25 \mathrm{wt} \%$ in water, $300 \mathrm{~mL}$ ). The combined organic layers were dried over anhydrous magnesium sulfate $\left(\mathrm{MgSO}_{4}\right)(48 \mathrm{~g})$ and concentrated in vacuum $\left(\mathrm{T}\right.$,bath $\left.=50^{\circ} \mathrm{C}\right)$. The crude product was purified by flash column chromatography on silica ( $250 \mathrm{~g})$. Eluent: heptanes/EtOAc 85:15 $v / v)$. This gave $10(11.69 \mathrm{~g}, 57.2 \mathrm{mmol}, 84 \%$ yield, HPLC purity $99.0 \%)$ as an orange oil.

$R_{\mathrm{f}}=0.35\left(\mathrm{EtOAc} /\right.$ heptane 3:7); ${ }^{1} \mathrm{H}$ NMR $\left(400 \mathrm{MHz}, \mathrm{CDCl}_{3}\right) \delta 10.60(\mathrm{~s}, 1 \mathrm{H}), 7.39(\mathrm{t}$, $J=8.1 \mathrm{~Hz}, 1 \mathrm{H}), 7.15(\mathrm{~d}, J=7.1,1 \mathrm{H}), 7.13(\mathrm{~d}, J=7.3,1 \mathrm{H}), 5.27(\mathrm{~s}, 2 \mathrm{H}), 3.50(\mathrm{~s}, 3 \mathrm{H}), 2.12(\mathrm{~s}$, $3 \mathrm{H}) ;{ }^{13} \mathrm{C}\left\{{ }^{1} \mathrm{H}\right\} \mathrm{NMR}\left(101 \mathrm{MHz}, \mathrm{CDCl}_{3}\right) \delta 190.7,158.5,134.2,127.53,127.49,126.3,115.1,95.0$, 93.2, 77.1, 56.6, 4.9; IR (neat) $\mathrm{cm}^{-1}: 2831$ (m, C(O)-H), 2750 (m, C(O)-H), 2235 (m, C $\left.\equiv \mathrm{C}\right)$, 1694 (s, C=O); HRMS (ESI) $m / z$ [M+H] ${ }^{+}$calcd for $\mathrm{C}_{12} \mathrm{H}_{13} \mathrm{O}_{3}: 205.0865$, found: 205.0874 .

\subsection{8-(Methoxymethoxy)-3-methylisoquinoline (6)}

In a $250 \mathrm{~mL}$ "mini-autoclave" (pressure tested to $10 \mathrm{bar}), 10(11.4 \mathrm{~g}, 55.8 \mathrm{mmol})$ and $\mathrm{NH}_{3}(7 \mathrm{~N}$ in $\mathrm{MeOH}, 160 \mathrm{~mL}$ ) were mixed. The reactor was sealed and submerged in an oil bath. The mixture was magnetically stirred at an external temperature of $65-76^{\circ} \mathrm{C}$ for $16 \mathrm{~h}$. At this point HPLC indicated $97.0 \%$ conversion of the starting material to product. The mixture was concentrated to dryness (final $p=41 \mathrm{mbar}$ ) in vacuum. The residue was mixed with potassium carbonate $\left(\mathrm{K}_{2} \mathrm{CO}_{3}\right)(35 \mathrm{wt} \%$ in water, $180 \mathrm{~mL})$ and EtOAc $(350 \mathrm{~mL})$. The layers were separated and the aqueous layer was extracted with $2 \times 350 \mathrm{~mL}$ EtOAc. The combined organic layers were washed with sodium chloride $(25 \mathrm{wt} \%$ in water, $480 \mathrm{~mL}$ ) and dried over $\mathrm{MgSO}_{4}(28 \mathrm{~g})$. The mixture was concentrated to dryness in vacuum (T,bath $=50{ }^{\circ} \mathrm{C}$, final $p=36$ mbar). The crude product was purified by flash column chromatography on silica (245 g). Eluent: heptanes/EtOAc 3:2 v/v). This gave 6 (10.04 g, $49.4 \mathrm{mmol}, 89 \%$ yield, HPLC purity $98.8 \%$ ) as yellowish crystals. 
$R_{\mathrm{f}}=0.33$ (EtOAc/heptane 1:1); m.p.: 50-52 ${ }^{\circ} \mathrm{C} ;{ }^{1} \mathrm{H}$ NMR $\left(400 \mathrm{MHz}, \mathrm{CDCl}_{3}\right) \delta 9.57(\mathrm{~s}$, $1 \mathrm{H}), 7.56(\mathrm{t}, J=8.0 \mathrm{~Hz}, 1 \mathrm{H}), 7.46(\mathrm{~s}, 1 \mathrm{H}), 7.35(\mathrm{~d}, J=8.0 \mathrm{~Hz}, 1 \mathrm{H}), 7.11(\mathrm{~d}, J=8.0 \mathrm{~Hz}, 1 \mathrm{H})$, $5.42(\mathrm{~s}, 2 \mathrm{H}), 3.55(\mathrm{~s}, 3 \mathrm{H}), 2.72(\mathrm{~s}, 3 \mathrm{H}) ;{ }^{13} \mathrm{C}\left\{{ }^{1} \mathrm{H}\right\}$ NMR $\left(101 \mathrm{MHz}, \mathrm{CDCl}_{3}\right) \delta 154.3,151.5,146.8$, $138.2,131.7,119.4,119.2,118.7,108.4,94.8,56.6,23.9$; IR (neat) $\mathrm{cm}^{-1}$ : 1629 (m, C=C); HRMS (ESI) $m / z[\mathrm{M}+\mathrm{H}]^{+}$calcd for $\mathrm{C}_{12} \mathrm{H}_{14} \mathrm{NO}_{2}$ : 204.1025, found: 204.1028.

\subsection{3-Methylisoquinolin-8-ol (12)}

In a $100 \mathrm{~mL}$ RB-flask with magnetic stirrer, oil bath and condenser, 6 (2.51 g, $12.3 \mathrm{mmol})$ and methanol $(\mathrm{MeOH})(40 \mathrm{~mL})$ were mixed. To the mixture was added hydrochloric acid $(36 \mathrm{wt} \%, 2.75 \mathrm{~mL})$. The mixture was heated at an external temperature of $69{ }^{\circ} \mathrm{C}$ for $2 \mathrm{~h}$ and then stirred at $15-25^{\circ} \mathrm{C}$ for $16 \mathrm{~h}$. At this point HPLC indicated $91.6 \%$ conversion of the starting material to product. The external temperature was raised to $70{ }^{\circ} \mathrm{C}$ and the mixture was stirred at this temperature for $3 \mathrm{~h}$. At this point HPLC indicated $99.8 \%$ conversion of the starting material to product. The mixture was concentrated to dryness in a vacuum (T,bath $=50^{\circ} \mathrm{C}$, final $p=198 \mathrm{mbar}$ ). The residue was mixed with potassium hydrogen carbonate $\left(\mathrm{KHCO}_{3}\right)(20 \mathrm{wt} \%$ in water, $50 \mathrm{~mL})$ and extracted with EtOAc $(3 \times 150 \mathrm{~mL})$. The combined organic layers were washed with sodium chloride $(25 \mathrm{wt} \%$ in water, $50 \mathrm{~mL})$ and dried over $\mathrm{Na}_{2} \mathrm{SO}_{4}(42 \mathrm{~g})$. The mixture was concentrated to dryness in a vacuum (final $p=29$ mbar). The crude product was stored in the freezer.

In a $250 \mathrm{~mL}$ 3-necked reactor with mechanical stirrer, heating mantle and condenser, 7 (11.0 g, $54.1 \mathrm{mmol})$ and $\mathrm{MeOH}(180 \mathrm{~mL})$ were mixed. To the mixture was added hydrochloric acid $(36 \mathrm{wt} \%, 12.0 \mathrm{~mL})$. The mixture was heated at $\sim 50{ }^{\circ} \mathrm{C}$ for $16 \mathrm{~h}$. At this point HPLC indicated $99.9 \%$ conversion of the starting material to product. The mixture was concentrated to dryness in a vacuum (T,bath $=50^{\circ} \mathrm{C}$, final $p=205 \mathrm{mbar}$ ). The residue was mixed with $\mathrm{KHCO}_{3}(20 \mathrm{wt} \%$ in water, $220 \mathrm{~mL})$ and extracted with EtOAc $(3 \times 650 \mathrm{~mL})$. The combined organic layers were washed with sodium chloride $(25 \mathrm{wt} \%$ in water, $350 \mathrm{~mL}$ ) and dried over $\mathrm{Na}_{2} \mathrm{SO}_{4}(103 \mathrm{~g})$. The mixture was concentrated to dryness in a vacuum (final $p=26$ mbar). The crude product was combined with the crude product from above and purified by flash column chromatography on silica (271 g). Eluent: DCM/MeOH 9:1 v/v. This gave 12 (9.52 g, $59.8 \mathrm{mmol}, 90 \%$ yield combined, HPLC purity 99.7\%) as brown crystals.

$R_{\mathrm{f}}=0.54\left(\mathrm{CH}_{2} \mathrm{Cl}_{2} / \mathrm{MeOH} 9: 1\right) ;$ m.p.: $202-203{ }^{\circ} \mathrm{C} ;{ }^{1} \mathrm{H}$ NMR $\left(400 \mathrm{MHz}, \mathrm{DMSO}-d_{6}\right) \delta$ $10.59(\mathrm{~s}, 1 \mathrm{H}), 9.35(\mathrm{~s}, 1 \mathrm{H}), 7.52-7.46(\mathrm{~m}, 2 \mathrm{H}), 7.23(\mathrm{~d}, J=8.2 \mathrm{~Hz}, 1 \mathrm{H}), 6.88(\mathrm{~d}, J=7.6 \mathrm{~Hz}, 1 \mathrm{H})$, $2.57(\mathrm{~s}, 3 \mathrm{H}) ;{ }^{13} \mathrm{C}\left\{{ }^{1} \mathrm{H}\right\}$ NMR $\left(101 \mathrm{MHz}, \mathrm{DMSO}-d_{6}\right) \delta 154.5,151.4,146.8,137.4,131.5,118.1$, 117.6, 116.1, 108.8, 23.8; IR (neat) $\mathrm{cm}^{-1}: 1633$ (m, C=C); HRMS (ESI) $m / z[\mathrm{M}+\mathrm{H}]^{+}$calcd for $\mathrm{C}_{10} \mathrm{H}_{10} \mathrm{NO}: 160.0762$, found: 160.0753 .

\subsection{Ethyl 2-((3-methylisoquinolin-8-yl)oxy)acetate (9)}

In a $250 \mathrm{~mL}$ 3-necked reactor equipped with mechanical stirrer and flushed with $\mathrm{N}_{2}$, $12(7.5 \mathrm{~g}, 47.1 \mathrm{mmol})$ and dimethylformamide $(\mathrm{DMF})(96 \mathrm{~mL})$ were mixed. The mixture was cooled to $0{ }^{\circ} \mathrm{C}$ and sodium ethanoate (NaOEt) $(3.54 \mathrm{~g}, 52.0 \mathrm{mmol})$ was added. The mixture was stirred at $\sim 0{ }^{\circ} \mathrm{C}$ for $1 \mathrm{~h}$. To the mixture was added ethyl bromoacetate $(5.7 \mathrm{~mL}$, $51.4 \mathrm{mmol}$ ) during $6 \mathrm{~min}$ at $\sim 0{ }^{\circ} \mathrm{C}$. The mixture was allowed to heat to $20-22{ }^{\circ} \mathrm{C}$ and stirred at this temperature for $19 \mathrm{~h}$ at which point no further conversion of the starting material was detected by HPLC. The mixture was concentrated to dryness in vacuum (T,bath $=50{ }^{\circ} \mathrm{C}$, final $p=0$ mbar). The residue was mixed with $340 \mathrm{~mL}$ water and $680 \mathrm{~mL}$ EtOAc and the phases separated. The aqueous layer was extracted with EtOAc $(2 \times 680 \mathrm{~mL})$. The combined organic layers were washed with water $(190 \mathrm{~mL})$ and concentrated to dryness (final $p=0$ mbar). The crude product was purified by flash column chromatography on silica (152 g). Eluent: DCM/MeOH 100:5 v/v). This gave 6 (6.27 g, HPLC purity 96.3\%) as brownish crystals and $2.36 \mathrm{~g} \mathrm{12}$, which was again subjected to the reaction conditions and purification. This provided additional 6 (2.13 g, HPLC purity 97.1\%) resulting in a total of $8.40 \mathrm{~g} 9$ (34.2 mmol, 73\% yield) 
An analytical sample was dissolved in ethanol $(\mathrm{EtOH})(1 \mathrm{~mL}), 3 \mathrm{~N} \mathrm{NaOH}(0.3 \mathrm{~mL}$, $0.9 \mathrm{mmol}$ ) was added and the mixture was stirred at $22{ }^{\circ} \mathrm{C}$ for $1 \mathrm{~h}$. The mixture was concentrated in vacuo, redissolved in water/acetone $(1: 2,1.5 \mathrm{~mL})$, and acidified to $\mathrm{pH} 3$ with $37 \%$ aqueous $\mathrm{HCl}$. The precipitate was collected by filtration and washed with water and acetone to give 2-((3-methylisoquinolin-8-yl)oxy)acetic acid as a pale yellow solid (0.12 g), which was characterized. $R_{\mathrm{f}}=0.64$ (acetone/AcOH/water 6:3:1); m.p.: $211-213{ }^{\circ} \mathrm{C} ;{ }^{1} \mathrm{H}$ $\operatorname{NMR}\left(400 \mathrm{MHz}, \mathrm{D}_{2} \mathrm{O}\right) \delta 9.70(\mathrm{~s}, 1 \mathrm{H}), 8.09(\mathrm{~s}, 1 \mathrm{H}), 8.04(\mathrm{t}, J=8.0 \mathrm{~Hz}, 1 \mathrm{H}), 7.67(\mathrm{~d}, J=8.0 \mathrm{~Hz}$, $1 \mathrm{H}), 7.21(\mathrm{~d}, J=8.0 \mathrm{~Hz}, 1 \mathrm{H}), 5.01(\mathrm{~s}, 2 \mathrm{H}), 2.81(\mathrm{~s}, 3 \mathrm{H}) ;{ }^{13} \mathrm{C}\left\{{ }^{1} \mathrm{H}\right\} \mathrm{NMR}\left(101 \mathrm{MHz}, \mathrm{D}_{2} \mathrm{O}\right) \delta 172.7$, 155.7, 142.8, 141.7, 140.3, 138.5, 123.7, 119.2, 118.3, 109.1, 66.0, 18.2; IR (neat) $\mathrm{cm}^{-1}: 1722$ $(\mathrm{m}, \mathrm{C}=\mathrm{O}), 1654(\mathrm{~s}, \mathrm{C}=\mathrm{C})$; HRMS (ESI) $\mathrm{m} / z[\mathrm{M}+\mathrm{H}]^{+}$calcd for $\mathrm{C}_{12} \mathrm{H}_{12} \mathrm{NO}_{3}: 218.0817$, found: 218.0815 .

\subsection{7-Methylfuro[3,2-h]isoquinolin-3(2H)-one (8)}

In a $100 \mathrm{~mL}$ RB-flask with magnetic stirrer, 9 (3.1 g, $12.7 \mathrm{mmol})$ was dissolved in EtOH (32 $\mathrm{mL})$. To the solution was added $\mathrm{NaOH}(3 \mathrm{~N}$ in water, $7.0 \mathrm{~mL}$ ). The mixture was stirred at $\sim 22{ }^{\circ} \mathrm{C}$ for $1 \mathrm{~h}$ at which point HPLC indicated $>99.9 \%$ conversion of the starting material. The mixture was concentrated to dryness in vacuum (T,bath $=40^{\circ} \mathrm{C}$, final $p=94 \mathrm{mbar}$ ). The residue was redissolved in acetone/water $(2: 1 \mathrm{v} / v, 38 \mathrm{~mL})$. To the mixture was added hydrochloric acid $(36 \mathrm{wt} \%, 2.0 \mathrm{~mL})$. At this point the $\mathrm{pH}$ of the mixture was $\sim 3$. The mixture was concentrated to dryness in vacuum (T,bath $=40{ }^{\circ} \mathrm{C}$, final $p=32 \mathrm{mbar}$ ). The residue was evaporated with DCM $(2 \times 40 \mathrm{~mL})$ to remove residual water and kept at high vacuum (oil pump) for $86 \mathrm{~min}$. The residue was mixed with $\mathrm{SOCl}_{2}(170 \mathrm{~mL})$ in a $250 \mathrm{~mL}$ 3-necked reactor. The temperature was increased to $70^{\circ} \mathrm{C}$ and the mixture was magnetically stirred at this temperature for $1 \mathrm{~h}$. The mixture was concentrated to dryness ( $\mathrm{T}$, bath $=50^{\circ} \mathrm{C}$, final $p=105$ mbar). The residue was mixed with $90 \mathrm{~mL} \mathrm{DCM}$ and stirred magnetically for 15 min at $\sim 22^{\circ} \mathrm{C}$. Salts were apparent in the mixture. To the mixture was added $\mathrm{AlCl}_{3}(16.8 \mathrm{~g}$, $126 \mathrm{mmol}$ ) and the mixture was stirred at $\mathrm{rt}$ for $30 \mathrm{~min}$. At this point HPLC indicated $99.0 \%$ conversion of the starting material into product. The mixture was added to $\mathrm{NaHCO}_{3}(6$ $\mathrm{wt} \%$ in water, $1.0 \mathrm{~L}$ ) at $12-17^{\circ} \mathrm{C}$ during $10 \mathrm{~min}$. To the mixture was added methyl tert-butyl ether (MTBE) (300 mL) and the resulting emulsion was filtered on a G-3 glass filter. The two-phase filtrate was transferred to a separatory funnel and the layers separated. The aqueous layer was extracted with $2 \times 300 \mathrm{~mL} \mathrm{MTBE}$. The pooled organic extracts were filtered and concentrated to a volume of $\sim 200 \mathrm{~mL}$ in vacuum $\left(\mathrm{T}\right.$,bath $=40{ }^{\circ} \mathrm{C}$ ) and then passed through silica $(20 \mathrm{~g})$ with MTBE $(800 \mathrm{~mL})$. The filtrate was concentrated to dryness in vacuum (T,bath $=40^{\circ} \mathrm{C}$, final $\left.p=32 \mathrm{mbar}\right)$. This gave $8(1.98 \mathrm{~g}, 9.9 \mathrm{mmol}, 79 \%$ yield, HPLC purity $96.7 \%$ ) as a brown solid.

$R_{\mathrm{f}}=0.7\left(\mathrm{CH}_{2} \mathrm{Cl}_{2} / \mathrm{MeOH} 95: 5\right) ;$ m.p.: $120-122{ }^{\circ} \mathrm{C}$ (Lit. [13] 119-122 $\left.{ }^{\circ} \mathrm{C}\right) ;{ }^{1} \mathrm{H}$ NMR $(400$ $\left.\mathrm{MHz}, \mathrm{CDCl}_{3}-d\right) \delta 9.54(\mathrm{~s}, 1 \mathrm{H}), 7.75(\mathrm{~d}, J=8.5 \mathrm{~Hz}, 1 \mathrm{H}), 7.56(\mathrm{~s}, 1 \mathrm{H}), 7.35(\mathrm{~d}, J=8.5 \mathrm{~Hz}$, 1H), 4.88 (s, 2H), 2.77 (s, 3H); ${ }^{13} \mathrm{C}\left\{{ }^{1} \mathrm{H}\right\} \mathrm{NMR}\left(101 \mathrm{MHz}, \mathrm{CDCl}_{3}\right) \delta 197.6,174.9,157.2,146.3$, 142.4, 124.3, 120.7, 119.9, 117.2, 115.5, 76.3, 24.6; IR (neat) $\mathrm{cm}^{-1}$ : 1697 (s, C=O), 1634 (s, $\mathrm{C}=\mathrm{C}$ ); HRMS (ESI) $\mathrm{m} / \mathrm{z}[\mathrm{M}+\mathrm{H}]^{+}$calcd for $\mathrm{C}_{12} \mathrm{H}_{10} \mathrm{NO}_{2}$ : 200.0712, found: 200.0716 . ${ }^{1} \mathrm{H} \mathrm{NMR}$ spectroscopic data was consistent with the literature [13].

\subsection{TMC-120B (1)}

In a $1 \mathrm{~L}$ 3-necked reactor with mechanical stirrer, condenser, heating mantle and addition funnel, acetone $(210 \mathrm{~mL})$ and p-toluene-sulfonic acid ( $p$-TsOH) $(4.58 \mathrm{~g}, 24.1 \mathrm{mmol})$ were mixed. The reactor was evacuated $\left(p<300\right.$ mbar) and backfilled with $\mathrm{N}_{2}$ three times. The temperature was increased to $56{ }^{\circ} \mathrm{C}$ (reflux). To the mixture was added a mixture of 8 $(3.5 \mathrm{~g}, 17.6 \mathrm{mmol})$, dichloroethane (DCE) $(210 \mathrm{~mL})$ and acetone $(40 \mathrm{~mL})$ (degassed with $\left.\mathrm{N}_{2}\right)$ during $2 \mathrm{~h}$ and $10 \mathrm{~min}$ while the temperature was gradually increased to keep the mixture at reflux. The mixture was stirred for $2 \mathrm{~h}$ at $\sim 67^{\circ} \mathrm{C}$ and then $\mathrm{NaHCO}_{3}(6 \mathrm{wt} \%$ in water, $500 \mathrm{~mL})$ was added. The mixture was extracted with EtOAc $(3 \times 800 \mathrm{~mL})$, washed with sodium chloride (25 wt $\%$ in water, $200 \mathrm{~mL}$ ) and dried over $\mathrm{MgSO}_{4}(54 \mathrm{~g})$. The mixture was concentrated to dryness in vacuum (T,bath $=40{ }^{\circ} \mathrm{C}$, final $p=44 \mathrm{mbar}$ ). The crude product 
was purified by flash column chromatography on silica (520 g. Eluent: DCM/EtOAc 1:0 -> 100:5 -> 9:1 v/v). This gave 1 as a yellow solid (1.11 $\mathrm{g}$, HPLC purity: $99.1 \%)$ and 1 as a yellow solid (0.35 g, HPLC purity: $98.3 \%)$ from less pure fractions, resulting in a total of $1.46 \mathrm{~g} 1$ (6.1 mmol, 35\% yield).

$R_{\mathrm{f}}=0.50\left(\mathrm{CH}_{2} \mathrm{Cl}_{2} / \mathrm{MeOH} 98: 2\right) ;$ m.p.: $174-176{ }^{\circ} \mathrm{C}$ (Lit. [13] 175-178 $\left.{ }^{\circ} \mathrm{C}\right) ;{ }^{1} \mathrm{H} \mathrm{NMR}$ $\left(400 \mathrm{MHz}, \mathrm{CDCl}_{3}\right) \delta 9.61(\mathrm{~s}, 1 \mathrm{H}), 7.92(\mathrm{~d}, J=8.5 \mathrm{~Hz}, 1 \mathrm{H}), 7.65(\mathrm{~s}, 1 \mathrm{H}), 7.44(\mathrm{~d}, J=8.5 \mathrm{~Hz}, 1 \mathrm{H})$, $2.84(\mathrm{~s}, 3 \mathrm{H}), 2.45(\mathrm{~s}, 3 \mathrm{H}), 2.26(\mathrm{~s}, 3 \mathrm{H}) ;{ }^{13} \mathrm{C}\left\{{ }^{1} \mathrm{H}\right\} \mathrm{NMR}\left(101 \mathrm{MHz}, \mathrm{CDCl}_{3}\right) \delta 181.9,164.0,154.4$, $145.7,144.9,141.9,135.2,126.1,121.1,120.7,120.2,114.8,23.5,20.6,17.8$. IR (neat) $\mathrm{cm}^{-1}$ : 1694 (s, C=O), 1657 (s, C=C); HRMS (ESI) $m / z[\mathrm{M}+\mathrm{H}]^{+}$calcd for $\mathrm{C}_{15} \mathrm{H}_{14} \mathrm{NO}_{2}$ : 240.1025, found: $240.1013 .{ }^{1} \mathrm{H}$ and ${ }^{13} \mathrm{C}$ NMR spectroscopic data was consistent with those reported in the literature $[1,13]$.

\section{Conclusions}

A concise total synthesis of the fungal natural product TMC-120B (1) has been presented. With an overall yield of $9 \%$ over seven steps to access 1 , this presents a significant improvement over previously reported total syntheses with $2.9 \%$ overall yield over 11 steps. The developed synthetic route enables more efficient access to the TMC-120B alkaloid for further biological evaluation in pursue of improved treatments for epilepsy. Such studies are currently undergoing and the results will be disclosed in due course.

Supplementary Materials: Copies of NMR and IR spectra for compounds 1, 5, hydrolyzed 6, and 7-10.

Author Contributions: Conceptualization, A.K.H., V.P., T.O.L. and M.H.C.; methodology, A.K.H., N.D.K., V.P. and K.P.L.; formal analysis, A.K.H. and N.D.K.; investigation, A.K.H., N.D.K., V.P. and K.P.L.; writing-original draft preparation, A.K.H., N.S.T. and M.H.C.; writing-review and editing, A.K.H., N.D.K. and M.H.C.; visualization, A.K.H.; supervision, V.P. and M.H.C.; project administration, M.H.C.; funding acquisition, T.O.L. and M.H.C. All authors have read and agreed to the published version of the manuscript.

Funding: This research received no external funding.

Institutional Review Board Statement: Not applicable.

Informed Consent Statement: Not applicable.

Data Availability Statement: Data is contained within the article.

Acknowledgments: We thank DTU Chemistry for an academic excellence PhD scholarship for N.S.T. We thank DTU for an alliance PhD scholarship for K.P.L. and for supporting the Gaius project (Discovery and PoC grant).

Conflicts of Interest: The authors declare no conflict of interest.

\section{References}

1. Kohno, J.; Hiramatsu, H.; Nishio, M.; Sakurai, M.; Okuda, T.; Komatsubara, S. Structures of TMC-120A, B and C, novel isoquinoline alkaloids from Aspergillus ustus TC 1118. Tetrahedron 1999, 55, 11247-11252. [CrossRef]

2. Kohno, J.; Sakurai, M.; Kameda, N.; Nishio, M.; Kawano, K.; Kishi, N.; Okudaand, T.; Komatsubara, S. Production, Isolation and biological properties of TMC-120A, B and C, novel inhibitor of eosinophil survival from Aspergillus ustus TC 1118. J. Antibiot. 1999, 52, 913-916. [CrossRef]

3. Copmans, D.; Kildgaard, S.; Rasmussen, S.A.; Ślezak, M.; Dirkx, N.; Partoens, M.; Esguerra, C.V.; Crawford, A.D.; Larsen, T.O.; de Witte, P.A.M. Zebrafish-based discovery of antiseizure compounds from the north sea: Isoquinoline alkaloids TMC-120A and TMC-120B. Mar. Drugs 2019, 17, 607. [CrossRef]

4. McNamara, J.O. Cellular and molecular basis of epilepsy. J. Neurosci. 1994, 14, 3413-3425. [CrossRef] [PubMed]

5. Duncan, J.S.; Sander, J.W.; Sisodiya, S.M.; Walker, M.C. Adult epilepsy. Lancet 2006, 367, 1087-1100. [CrossRef]

6. GBD 2016 Epilepsy Collaborators. Global, regional, and national burden of epilepsy, 1990-2016: A systematic analysis for the Global Burden of Disease Study 2016. Lancet Neurol. 2019, 18, 357-375, Erratum in Lancet Neurol. 2019, 18, e4. PMID:30773428. PMCID:PMC6416168. [CrossRef]

7. Schmidt, D.; Schachter, S.C. Drug treatment of epilepsy in adults. BMJ 2014, 348, 2546-2563. [CrossRef] [PubMed] 
8. Franco, V.; French, J.A.; Perucca, E. Challenges in the clinical development of new antiepileptic drugs. Pharmacol. Res. 2016, 103, 95-104. [CrossRef] [PubMed]

9. Ogawa, A.; Murakami, C.; Kamisuki, S.; Kuriyam, I.; Yoshid, H.; Sugawara, F.; Mizushinac, Y. Pseudodeflectusin, a novel isochroman derivative fromAspergillus pseudodeflectus a parasite of the sea weed, Sargassum fusiform, as a selective human cancer cytotoxin. Bioorg. Med. Chem. Lett. 2004, 14, 3539-3543. [CrossRef] [PubMed]

10. Brown, W.C.; Schiffman, D.O.; Swinyard, E.A.; Goodman, L.S. Comparative assay of an antiepileptic drugs by psychomotor seizure test and minimal electroshock threshold test. J. Pharmacol. Exp. Ther. 1953, 107, 273-283.

11. Copmans, D.; Crawford, A.; de Witte, P.; Esguerra, C.; Kildgaard, S.; Larsen, T.O.; Ny, A. Treatment of Epilepsy. US Patent US2020179370A1, 11 June 2020.

12. Kumemura, T.; Choshi, T.; Hirata, A.; Sera, M.; Takahashi, Y.; Nobuhiro, J.; Hibino, S. A Total Synthesis of a New Type of Furo [3, 2-h] isoquinoline Alkaloid, TMC-120B. Heterocycles 2003, 61, 13-17. [CrossRef]

13. Kumemura, T.; Choshi, T.; Hirata, A.; Sera, M.; Takahashi, Y.; Nobuhiro, J.; Hibino, S. Synthesis of the New Furo [3, 2-h] isoquinoline Alkaloid, TMC-120B from Aspergillus ustus. Chem. Pharm. Bull. 2005, 53, 393-397. [CrossRef] [PubMed]

14. Choshi, T.; Kumemura, T.; Fujioka, H.; Hieda, Y.; Hibino, S. Improved Synthesis of the New Furo[3,2-h]isoquinoline Alkaloids TMC-120B and TMC-120A, and Their Inhibitory Activities against IFN- $\gamma$ and IL-4 Production. Heterocycles 2012, 84, 587-595. [CrossRef]

15. Gao, S.; Wu, Z.; Fang, X.; Lin, A.; Yao, H. Palladium-Catalyzed Dearomative Allylic Alkylation of Indoles with Alkynes to Synthesize Indolenines with C3-Quarternary Centers. Org. Lett. 2016, 18, 3906-3909. [CrossRef]

16. Rafael, C.; Carmen, N. The Sonogashira Reaction: A Booming Methodology in Synthetic Organic Chemistry. Chem. Rev. 2007, 107, 874-922.

17. Roesch, K.R.; Larock, R.C. Synthesis of Isoquinolines and Pyridines by the Palladium- and Copper-Catalyzed Coupling and Cyclization of Terminal Acetylenes. Org. Lett. 1999, 1, 553-556. [CrossRef]

18. Sakamoto, T.; Numata, A.; Kondo, Y. The cyclization reaction of ortho-ethynylbenzaldehyde derivatives into isoquinoline derivatives. Chem. Pharm. Bull. 2000, 48, 669-672. [CrossRef]

19. Ivanova, O.A.; Andronov, V.A.; Vasin, V.S.; Shumsky, A.N.; Rybakov, V.B.; Voskressensky, L.G.; Trushkov, I.V. Expanding the Reactivity of Donor-Acceptor Cyclopropanes: Synthesis of Benzannulated Five-Membered Heterocycles via Intramolecular Attack of a Pendant Nucleophilic Group. Org. Lett. 2018, 20, 7947-7952. [CrossRef]

20. Hwang, S.; Lee, Y.; Lee, P.H.; Shin, S. AgOTf and TfOH co-catalyzed isoquinoline synthesis via redox reactions of O-alkyl oximes. Tetrahedron Lett. 2009, 50, 2305-2308. [CrossRef]

21. Dieckmann, W. Zur Kenntniss der Ringbildung aus Kohlenstoffketten. Ber. Dtsch. Chem. Ges. 1894, 27, 102-103. [CrossRef]

22. Friedel, C.; Crafts, J.M. Sur une nouvelle méthode générale de synthèse d'hydrocarbures, d'acétones, etc. Compt. Rend. 1877, 84, $1392-1450$ 